İş ve İnsan Dergisi I The Journal of Human and Work

Y1l | Year: Ekim | October 2016

Cilt-Say1 | Volume-Issue:3(2)

ss | pp: $93-107$

doi: 10.18394/iid.50780

e-ISSN 2148-967X

http://dergipark.ulakbim.gov.tr/iid/

Araştırma Makalesi

\title{
Askeri Liderlikle Astların Liderden Tatmininde Astların Kişilik Özelliklerinin Düzenleyici Rolü
}

\author{
Moderating Role of Subordinates' Personality Traits on the Relationship between \\ Military Leadership and Subordinates' Satisfaction with Leaders
}

\author{
Mehmet Kahya" \\ Kara Harp Okulu
}

Faruk Şahin

Muğla Sitk1 Koçman Üniversitesi

\section{MAKALE BILLGİSI}

Anahtar Kelimeler:

Askeri Liderlik, Liderden

Duyulan Tatmin, Bes Faktör

Kisilik Özellikleri

Tarihler:

Geliş 01 Temmuz 2016

Düzeltme gelis 27 Eylül 2016

Kabul 28 Eylül 2016

\section{A R TICLE INFO}

\section{Keywords:}

Military Leadership,

Satisfaction with Leader.

Five-Factor Personality

Traits

Article history:

Received 01 July 2016

Received in revised form 27

September 2016

Accepted 28 September 2016

\begin{abstract}
ÖZ
Bu araştırma askeri liderlikle astların liderden tatmini arasındaki ilişkide astların kişilik özelliklerinin düzenleyici etkisini belirlemek maksadıla savunma sanayindeki bir kurumun 390 çalışanı üzerinde yapılmıştır. Araştırmada kullanılan ölçeklerin uyumu Doğrulayıcı Faktör Analizi ile, değişkenler arasındaki ilişkiler korelasyon ve basit regresyon analizi ile, kişiliğin düzenleyici etkisi ise düzenleyici değişkenli hiyerarşik regresyon analizi ve eğim testi analizi ile test edilmiştir. Korelasyon analizi sonucu askeri liderlikle liderden tatmin arasında pozitif yönde ilişki bulunduğu; regresyon analizi sonucunda, askeri liderliğin asta yönelik ilgi ve farkındalık boyutlarının astların liderden tatminini etkilediği; beş faktör kişilik özelliklerinden gelişime açıklı̆̆ın bu ilişkide düzenleyici rolü bulunduğu tespit edilmiştir. Elde edilen bulgular Kaynakların Korunması Teorisi çerçevesinde tartışılarak, yazına ve uygulamaya katkısı açıklanmış ve gelecek araştırmalar için önerilerde bulunulmuştur.
\end{abstract}

\footnotetext{
Bu makale, birinci yazarın Kara Harp Okulu Savunma Bilimleri Enstitüsünde hazırlamakta olduğu doktora tezinden türetilmiştir.

* Iletişim Kurulacak Yazar: Mehmet Kahya, Kara Harp Okulu, Savunma Bilimleri Enstitüsü, Ankara, Türkiye. E-posta: mkahya@kho.edu.tr
} 


\section{GİRIŞ}

Liderlerin astlarına karşı gösterdikleri liderlik davranışları, astların tutum ve davranışlarını olumlu yönde etkilemektedir (Horn, 2008). Özellikle liderlerin astlarına yönelik bireysel ilgi göstermesinin, astların liderden duydukları tatmini olumlu yönde etkileyeceğine yönelik yazında bulgular (Stogdill, 1974; Wood \& Sobel, 1970; Yukl, 2010) bulunmaktadır. Liderlik davranışının gösterildiği alanlardan birisi de askeri ortamlardır. Askeri ortamlarda lider-ast ilişkisinin olumlu olması ve liderin astına yönelik sergileyeceği liderlik davranışı, görevin başarılması için önem arz ederek, astın liderinden tatminini etkilemektedir. Askeri ortamlardaki liderlik tarzı bireylerin orduda kalma niyetini de olumlu yönde etkilemektedir (Randall, 2006). Askeri ortamlarda sergilenen ve son dönemde yerli yazında geliştirilen liderlik tarzlarından birisi de askeri liderliktir.

Yapılan yazın taramasında askeri liderlik konusunda yapılan çalışmalarda daha çok askeri liderlerin sahip olması gereken özellikler ve değerlere odaklanıldığı (Aude, Karrasch, Leonard \& Hatfield, 2006; Hunt, 1991; Mumford, Zaccaro, Harding, Jacobs \& Fleishman, 2000; Tabak, 1997), askeri liderlikle çıktılar arasındaki ilişkilere çok az odaklanıldığg (Künter, 2014) tespit edilmiştir. Dilek (2005) Kara Kuvvetleri Komutanlığı Sarıkamış Garnizonunda görev yapan tabur, bölük, takım, kısım komutanları (subay, astsubay) ve profesyonel askerler (uzman erbaş) örneklemi üzerinde yaptığ 1 çalışmasında liderlik tarzlarının (dönüştürücü, etkileşimci) astların iş tatminlerini pozitif yönde anlamlı olarak etkilediğini tespit etmiş; ileriye yönelik olarak çalışmanın farklı askeri ve özel sektör örnekleminde tekrarlanmasını önermiştir. Askeri liderlik ölçeğini geliştiren Künter (2014) çalışmasında askeri liderliğin her üç boyutunun da astların liderden tatminini yordadığı bulgusuna ulaşmış ve ileriye yönelik olarak, farklı değişkenlerin aracılık ve düzenleyicilik rolünün incelenmesini önermiştir.

$\mathrm{Bu}$ çalışmada askeri liderlikle astların liderden tatmini arasındaki ilişkide astların kişilik özelliklerinin düzenleyici etkisi incelenmiştir. Kuramsal olarak "Kaynakların Korunması Teorisi"ne (Hobfoll, 1989) dayanan çalışmada öncelikle değişkenler arasındaki ilişkiler kuramsal çerçevede ele alınarak araştırma hipotezleri oluşturulmuş, müteakiben korelasyon ve regresyon analizleri ile hipotezler test edilmiştir. Elde edilen bulgular tartışılarak, çalışmanın yazına ve uygulamaya katkısı açıklanmış, gelecek araştırmacılara önerilerde bulunulmuştur.

\section{KURAMSAL ÇERÇEVE VE HIPPOTEZLER}

\subsection{Askeri Liderlik ve Liderden Duyulan Tatmin}

Liderin başarılı bir liderlik gösterebilmesi için izleyenlerinin üzerinde etkili olması ve onlar tarafından lider olarak kabul edilmiş olması gerekmektedir. Andrews (2009: 18) "eylemler kelimelerden daha yüksek sesle konuşurlar" diyerek, liderin sadece emir veren değil aynı zamanda bizzat uygulayarak gösteren ve astlarına örnek olan bir rol model olmaları gerektiğini ifade etmektedir. $\mathrm{Bu}$ ifadeden hareketle, örgüt içerisinde liderin kendisinin ve astlarına yaklaşımının etkin liderliğin oluşumunda önemli bir faktör olduğu belirtilebilir.

Askerlik mesleği yapısı, katı emir-komuta ilişkisi, yüksek belirsizlik ortamlarında görev alınması ve muharebe ortamında personelin yaşam tehlikesinin söz konusu olması gibi özellikleri nedeniyle diğer meslek ve ortamlara göre farklılık arz eder. Erkek egemen olan askeri ortamlarda, başarıya ulaşmak için kritik bir faktör olarak kabul edilen liderliğin özellikle muharebe ortamı gibi belirsizliğin yüksek olduğu ortamlarda astların sevk ve idaresindeki önemi büyüktür (Eagly, Karau \& Maghijani, 1995; Bass, 1990; Horn \& Walker, 2008). ABD Ordusu Sahra Talimnamesi Field Manual (FM) 22-100 (1999: 1-4) liderliğin; örgütün geliştirilmesi ve görevin başarılmasını yürütürken, hedef, yön ve motivasyon sağlayarak bireyleri etkileyeceğini; dolayısıyla liderlik tanımının "geliştirme", "yürütme" ve "etkileme"yi içeren üç eyleme odaklandığını vurgulamaktadır. Talimname bu eylemleri "ol-bil-yap" (be-know-do) kisaltmasiyla yapılandırmaktadır.

Askeri liderlik kısaca "görevin başarılmasına yönelik hedef ve yön göstererek astlarını yönetme, geliştirme ve etkileme süreci" olarak tanımlanabilir. Taylor, Rosenbach ve Rosenbach (2009) askeri liderliğin ilkelerini "görev bilinci, bağlılık, dinleme, harekete geçme, adalet, bilgi, örnek olma, hazır bulunuş, şeref" olarak; etkili ve dönüştürücü bir lider olmak için sahip olunması gereken zorunlu özellikleri de "tarafsızlık, ikna, bağlılık, dil ve değerler, hazır bulunuş, etkileme" olarak belirtmektedirler. Tabak (1997) FM 22-100 Liderlik Talimnamesi ve Askerlik Mesleğinin Değerleri'nde belirtilen stratejik, operatif ve taktik düzeyde liderlerin sahip olması gereken 41 yetenek ve değerden yola çıkarak yapmış olduğu çalışmasında, birlik komutanı olan askeri liderlerin sahip olması gereken temel özellikleri "fedakarlık, birliğe bağlılık, dürüstlük, inisiyatif, sadakat" olarak belirlemiştir. Künter (2014) askeri liderliğin "asta 
yönelik ilgi", "işe yönelik ilgi" ve "farkındalık" olmak üzere üç boyuttan oluştuğunu ifade etmektedir. "Asta yönelik ilgi" liderin, astını tanıma, sorunları ile ilgilenme ve adil olma gibi hususları içeren ve daha çok bireylerarası ilişkiye ağırlık veren; "işe yönelik ilgi", mesleğe bağlılık ve çalışkanlığın ön plana çıktığı; "farkındalık" ise etrafta gelişen durumlardan haberdar olma, özgüven ve zekâ gibi hususları içeren boyutudur (Künter, 2014). Askeri ortamlarda astlar üzerinde olumlu etki yaratarak, huzurlu bir çalışma ortamının sağlanması nedeniyle "asta yönelik ilgi" boyutu liderde sahip olunması gereken özellikler arasındadır. Diğer yandan liderlerin, askeri ortamların doğasında disiplin ve görevin tam olarak yapılmasinın bulunmasi (Edwards, 2008) ve hiyerarşik kademelerde gücün nasıl kullanılacağ ile lider-ast arasındaki etkileşimin nasıl olmasının beklendiğinin çoğu durumda açık olarak belirtilmesi (Wong, Bliese \& McGurk, 2003) nedeniyle "işe yönelik ilgi" boyutuna sahip olması gerekmektedir. Sürekli değişen ve belirsizliğin hâkim olduğu koşullarda liderin vereceği doğru kararlarla kurumsal tehditlerin bertaraf edilebilmesi nedeniyle "farkındalık" boyutunun da liderlerde sahip olunması gereken özelliklerden olduğu değerlendirilmektedir.

İş tatmini çoğunlukla "işin kendisi" ve "amirle ilişkiler" gibi unsurları içermektedir (Morris, 1995). Liderlik tarzı ile tatmine yönelik araştırmalar, liderlik tarzının çalışan tatminini etkilediğini ifade etmektedir (Fernandez, 2008; Stogdill, 1974). Alan yazında ilişki odaklı liderliğin (Fiedler, 1954; Fiedler, Bass \& Fiedler, 1961; Meuwese, 1964; Wood \& Sobel, 1970; Künter, 2014), görev odaklı liderliğin (Downey, Sheridan \& Slocum, 1975; Vecchio, 1981; Dobbins \& Zaccaro, 1986; Wells \& Peachey, 2011; Künter, 2014) ve farkındalığ1 yüksek liderliğin (Künter, 2014) astlarda yüksek tatmine yol açacağına yönelik çalışmalar bulunmaktadır. Judge, Piccolo ve Ilies (2004) yapmış oldukları meta-analiz çalışmasında liderliğin bireye ilgi ve yapıyı harekete geçirme boyutları ile astın liderden tatmini arasında pozitif yönde anlamlı ilişki tespit etmişstir.

Yazın taraması sonucu ulaşılan bilgiler değerlendirildiğinde; çalışmanın ilk hipotezi aşağıdaki gibidir:

Hipotez 1: Askeri liderlikle astların liderden tatminleri arasında pozitif yönde bir ilişki vardır.

\subsection{Askeri Liderlik - Liderden Duyulan Tatmin İlişkisinde Kişiliğin Düzenleyici Etkisi}

Lider kişilerin astlarına yönelik sergileyeceği liderlik tarzı astların liderden tatmini etkilemekle birlikte, bu ilişki astların kişilik özelliklerine göre değişebilmektedir. Abdel-Halim ve Rowland (1976) iş çevresinde algılanan özerkliğin kişilerarası faktörlerin (örn. lider - çalışan iletişimi) ya da yapılan görevin doğasının yansıması olduğunu belirterek; çalışanın, bağımsızlık ihtiyacı kuvvetli iken (örn. yapılandırılmamış iş ya da rutin olmayan işi varsa) karar verme eyleminin merkezde (liderde) toplandığ 1 algısına sahipse, işinden ya da liderinden tatmin olmayacağını ifade etmektedir. Tosi (1973) liderlerinin serbestlik toleransını yüksek olarak tanımlayan astların, liderlerinin serbestlik toleransını düşük olarak tanımlayan astlara nazaran daha düşük iş tatmini yaşadıklarını ve otoriterliği yüksek olanların, düşük olanlara nazaran daha fazla iş tatmini algıladıklarını belirtmektedir. Dobbins ve Zaccaro (1986) yapmış oldukları çalışmada liderin bireye ilgisi ile astın liderden tatmini arasında grup dayanışmasının düzenleyici etkisi olduğunu tespit ederek; grup dayanışması düşük iken düşük dayanışma grubunda amirden tatminlerinin yüksek dayanışma grubuna nazaran daha pozitif olduğu bulgusuna ulaşmışlardır.

Astların kişilik özelliklerinin askeri liderlik tarzı ile liderden tatmin arasındaki ilişkide düzenleyici etkisinin bulunacağ 1 beklenmektedir. Liderin "asta yönelik ilgi" ve "farkındalık" tarzlarını sergilemesi durumunda, özdisiplini, uyumluluğu, dişa dönüklüğü ve gelişime açıklığı yüksek olan astların liderden tatminlerinin de daha yüksek olacağı; "işe yönelik ilgi" liderlik tarzını sergilemesi durumunda ise özdisiplini yüksek olan astların liderden tatminlerinin daha yüksek olacağı; ancak nevrotikliği yüksek olan astların ise liderden tatminlerinin daha düşük olacağı beklenmektedir.

Yazın taraması sonucu ulaşılan bilgiler değerlendirildiğinde; bu çalışmanın ikinci hipotezi aşağıdaki gibidir:

Hipotez 2: Askeri liderlikle astların liderden tatminleri arasındaki ilişkide astların kişilik özelliklerinin düzenleyici etkisi bulunmaktadır.

Askeri liderlikle astların tutum ve davranışları arasındaki ilişkide astların kişilik özelliklerinin düzenleyici rolünün olabileceğine yönelik düşünce kuramsal olarak Kaynakların Korunması Teorisine dayandırılmaktadır. Kaynakların Korunması Teorisinin temel ilkesine göre insanlar değer verdikleri şeyleri kazanmak, elde tutmak ve korumak için uğraşırlar (Hobfoll, 1989; Hobfoll \& Lilly, 1993). Teoriye göre, bireyler için değerli olan kaynaklar, dört grupta toplanır: "nesnel kaynaklar, koşullar, kişisel özellikler ve enerji” (Hobfoll, 1989). Bireylerin strese karşı dayanıklılığını artıran "kişisel özellikler" ve bireyin sahip olduğu beceriler, bireyin içinde bulunduğu koşullara uyum 
sağlamasını kolaylaştırır (Hobfoll \& Shirom, 2001). Kaynakların Korunması Teorisi, bireylerin kayıplarla nasıl mücadele ettiği ve kaynakları nasıl kullandığını etkilemesi nedeni ile kişisel özellikleri kaynak olarak ele almaktadır (Hobfoll \& Shirom, 2001). Stresli bir durumda birey, kaybedilen kaynağın yerini başka kaynaklarla doldurmak zorundadır (Hobfoll, 1989). Bu nedenle, iş taleplerini karşılamak için kişisel kaynakların uygunluğu, çalışanlarda bu taleplerin etkisini belirlemektedir (Benoliel \& Somech, 2014; Hobfoll \& Lilly, 1993). Bu açıdan bakıldığında, çalışanların kişilik özellikleri, çalışan çıktılarında askeri liderliğin olumlu ya da olumsuz etkilerini kuvvetlendirmede veya tersi olarak azaltmada önemli bir rol oynayabilir.

\section{YÖNTEM}

\section{1. Örneklem ve İşlem}

Araştırmanın evrenini savunma sanayinde faaliyet gösteren ve yaklaşık 100.000 personeli bulunan bir kurumun çalışanları oluşturmaktadır. Araştırmanın örneklemini ise kurumun 390 çalışanı oluşturmaktadır. Araştırmada veri toplama aracı olarak anket tekniği kullanılmıştır. Araştırmada kullanılan anket, katılımcılara araştırma hakkında bilgi verilmesine müteakip ilk yazar tarafindan elden dağıtılmış ve aynı yöntemle geri toplanmıştır. Araştırmada ortak yöntem varyansını azaltmaya yönelik olarak veriler iki farklı zamanda toplanmıştır. İlk safhada, bağımsız değişken (askeri liderlik) ve düzenleyici değişken (astların kişiliği) verileri elde edilmiş; ikinci safhada ise (yaklaşık bir ay sonra), bağımlı değişken (astların liderden duydukları tatmin) verileri toplanmıştır. $\mathrm{Bu}$ araştırmada liderler, katılımcıların (ast) bağlı oldukları bir üst düzeydeki amirlerini ifade etmektedir.

Toplanan veriler SPSS 22.0 paket programı ve AMOS 21.0 Programı kullanılarak analiz edilmiştir. Demografik verilerin analizi Frekans Analizi; değişkenler arasındaki ilişki ise Korelasyon Analizi yapılarak incelenmiştir. Askeri liderlik ölçeğinin faktör yapısının belirlenmesi için Temel Bileşenler Analizi, modelin uyumunun belirlenmesi ve ölçeklerin boyutlandırılması için Doğrulayıcı Faktör Analizi yapılmıştır. İlk hipotezin testinde Basit Regresyon Analizi; ikinci hipotezin testinde ise Hiyerarşik Doğrusal Regresyon Analizi yardımıyla moderatör analizi yapılmıştır.

\section{2. Ölçekler}

Askeri Liderlik Ölçeği. Askeri liderliğin ölçümünde, Künter (2014) tarafindan geliştirilen, 3 boyutlu (asta yönelik ilgi, işe yönelik ilgi, farkındalık) ve 33 maddeli Askeri Liderlik Ölçeği kullanılmıştır. Künter (2014) geliştirmiş olduğu ölçeğin güvenilirlik katsayısının $(\alpha) \quad 98$ (alt boyutlar sırasıyla .98; .96; .95) olduğunu tespit etmiştir. Ölçek ast durumunda bulunan kişilere yöneltilerek, liderlerini (bir üst düzeydeki amirleri) değerlendirmeleri sağlanmıştır. 7'li Likert Tipinde $(1=$ Kesinlikle katılmıyorum, $7=$ Tamamen katılıyorum) tasarlanan ölçeğin örnek maddesi “Kim olursa olsun insana değer verir"dir. Ölçeğin yeni geliştirilmiş olması nedeniyle, ölçeğin faktör yapısını belirlemek maksadıyla kurumun intranet ağı üzerinden pilot uygulama yapılmış ve anketi dolduran 276 çalışanın verileri temel bileşenler analizine tabi tutulmuştur. Analiz sonucunda, ölçeğin aslına benzer şekilde 3 faktör altında boyutlandırılabileceği, K-M-O değerinin .974, açıklanan varyans oranının $\% 76.54$, güvenilirlik değerinin .982 olduğu görülmüştür. Asıl uygulamada ölçeğin güvenilirlik değeri 970 (alt boyutlar sirasiyla .96, .89 ve .90) olarak bulunmuştur.

Liderden Duyulan Tatmin Ölçeği. Astların liderlerinden duydukları tatmin, Spector (1985) tarafından geliştirilen ve Sun (2002) tarafından Türkçe'ye uyarlanan iş tatmin ölçeğinin liderden duyulan tatmini ölçümleyen 6 maddesi kullanılarak ölçülmüştür. Ölçek, 7'li Likert Tipi (1= Kesinlikle katılmıyorum, 7= Kesinlikle katılıyorum) ve tek boyutlu olup, örnek maddesi "Amirim bana karş1 adil davranır" ifadesidir. Bu çalışmada ölçeğin güvenilirlik değeri $(\alpha) .834$ olarak bulunmuştur.

Beş Faktör Kişilik Ölçeği. Astların kişilik özellikleri Benet-Martinez ve John (1998) tarafindan geliştirilen, 44 maddelik ve “dışadönüklük, uyumluluk, özdisiplin, nevrotiklik ve gelişime açıklık" boyutlarından oluşan Beş Faktör Kişilik Ölçeği ile ölçülmüştür. Ölçeğin Türkçe uyarlaması; Schmitt, Allick, McCrae \& Benet-Martinez (2007) tarafından 56 ülke kapsamında bireylerin kendilerini tanımlama profili ve örüntüleri konusunda yapılan bir çalışmanın Türkiye ayağı kapsamında Sümer ve Sümer (2005) tarafindan yapılmıştır. Belirtilen çalışmada beş faktör kişilik ölçeğinin Cronbach Alfa güvenilirlik değerleri sirasiyla .79, .70, .78, .79 ve .76 olarak bulunmuştur (Schmitt, vd., 2007). 7'li Likert Tipi ( $1=$ Hiç katılmıyorum, $7=$ Tamamen katılıyorum) olan ölçeğin örnek maddesi "Affedici bir yapıya sahip" ifadesidir. Bu çalışmada ölçeğin güvenilirlik değeri $(\alpha) .651$ (alt boyutlar sirasiyla .717, .691, $.673, .697$ ve 726 ) olarak bulunmuştur. 
Tablo 1: Değişkenlere Ait DFA (N=390)

\begin{tabular}{lcccccccc}
\hline \multicolumn{1}{c}{ Ölçek } & $\boldsymbol{\Delta} \boldsymbol{\chi}^{2}$ & $\mathbf{s d}$ & $\boldsymbol{\Delta} \boldsymbol{\chi}^{2} / \mathbf{s d}$ & $\mathbf{R M S E A}$ & GFI & AGFI & CFI & IFI \\
\hline $\begin{array}{l}\text { Askeri Liderlik (İkincil düzey üç̧ } \\
\text { faktörlü model) }\end{array}$ & 156,66 & 41 & 2,68 &, 06 &, 93 &, 89 &, 97 &, 97 \\
$\begin{array}{l}\text { Kişilik (İkincil düzey beş faktörlü } \\
\text { model) }\end{array}$ & 342,51 & 86 & 3,98 &, 08 &, 89 &, 85 &, 85 &, 85 \\
$\begin{array}{l}\text { Liderden Tatmin (Birincil düzey tek } \\
\text { faktörlü model) }\end{array}$ & 22,35 & 8 & 2,79 &, 06 &, 98 &, 95 &, 98 &, 98 \\
\hline
\end{tabular}

\section{BULGULAR}

Araştırmaya katılanların tamamı erkektir. Katılımcıların yaş ortalaması 30.08 (s.s.=5.99), mesleki deneyim ortalamasi 7.49 (s.s.=6.93), liderleriyle birlikte çalışma süresi ortalaması 1.78 (s.s.=1.04) yıldır. Katılımcıların çoğunluğu (\%52.8) lise mezunudur ve \%62.6's1 $(n=244)$ evlidir.

Araştırmada kullanılan ölçeklerin faktör yapısını doğrulamak maksadıyla Doğrulayıcı Faktör Analizi (DFA) yapılmıştır. Analiz sonucu elde edilen uyum iyiliği değerleri Tablo 1'de gösterilmiştir. Analizler sonucunda değişkenlerin iyi / kabul edilebilir uyum iyiliği değerlerine sahip olduğu görülmüştür.

Tablo 2'de korelasyon analizi sonucu elde edilen değişkenler arasındaki ortalama, standart sapma ve korelasyon değerleri gösterilmektedir.

Tablo 3'e göre hiyerarşik regresyon analizi sonuçları birinci gruptaki kontrol değişkenlerinin regresyon modeline anlamlı bir katkısının olmadığını göstermektedir $\left[\mathrm{F}_{(6,390)}=2.08, \mathrm{p}>0.05\right]$.
İkinci grupta yer alan asta yönelik ilgi, işe yönelik ilgi ve farkındalık değişkenlerinin regresyona girilmesi, liderden tatmindeki \%45.4'lük ilave varyansı açıklamış ve $\mathrm{R}^{2}$ deki bu değişim anlamlı bulunmuştur $\left[\mathrm{F}_{(9,390)}=39.64, \quad \mathrm{P}<.001\right]$. Bütün bağımsız değişkenler regresyona girildiğinde asta yönelik ilginin $(\beta=0.507, p<0.001)$ ve farkındalık boyutunun $(\beta=0.186, p<0.01)$ amirden tatmin üzerinde anlamlı etkisi olduğu görülmüştür. Tüm bağımsız değişkenlerin, amirden tatmindeki \%47.4 oranındaki varyansı açıkladığı görülmüştür. $\mathrm{Bu}$ doğrultuda ilk hipotez "kısmen" desteklenmiştir.

Askeri liderlikle astların tutum ve davranışları arasındaki ilişkide astların kişilik özelliklerinin düzenleyici etkisini test etmek maksadıyla düzenleyici değişkenli çoklu hiyerarşik regresyon (Moderated Multiple Regression) analizi yapılmıştır. Bir değişkenin düzenleyici değişken olabilmesi için; bu değişkenin bağımsız değişkenle olan etkileşiminin, bağımlı değişken üzerinde anlamlı olması ve ilişkinin yönünü ya da şiddetini değiştirmesi gerekmektedir (Baron \& Kenny, 1986). Aiken ve West (1991) düzenleyici değişken analizinde sürekli değerlerin öncelikle standardize

Tablo 2: Değişkenler Arasındaki Korelasyon Analizi Sonuçları (N=390)

\begin{tabular}{|c|c|c|c|c|c|c|c|c|c|c|c|}
\hline 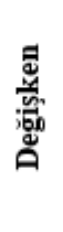 & 范 & 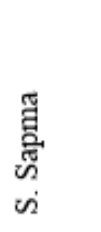 & 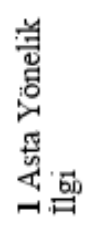 & 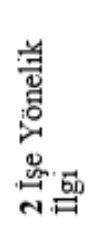 & 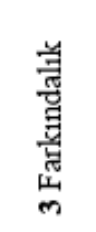 & $\begin{array}{l}\text { 学 } \\
\text { 형 } \\
5 \\
\text { 总 } \\
+\end{array}$ & $\begin{array}{l}\text { 总 } \\
\text { 总 } \\
\text { 惫 } \\
\text { 总 } \\
\text { in }\end{array}$ & 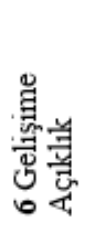 & 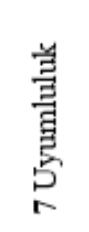 & 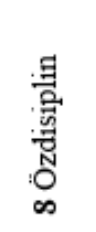 & 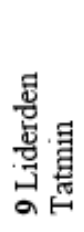 \\
\hline 1 & 5,32 & 1,26 & - & & & & & & & & \\
\hline 2 & 5,74 & 1,11 & $.70^{\star \star}$ & - & & & & & & & \\
\hline 3 & 5,79 & 99 &, $75^{\star \star}$ &, $70^{\star \star}$ & - & & & & & & \\
\hline 4 & 3,03 & 1,00 &,$- 11^{\star}$ &,- 07 &,$- 11^{\star}$ & - & & & & & \\
\hline 5 & 4,96 & ,95 &, 08 &, 09 &, $11^{*}$ &,$- 42^{\star *}$ & - & & & & \\
\hline 6 & 5,10 & 83 &, 07 &, 03 &, 09 &,$- 25^{\star *}$ &, $\mathbf{4 8}$ & - & & & \\
\hline 7 & 5,41 &, 70 &, $20^{\star \star}$ &, $22^{\star \star}$ &, $25^{\star \star}$ &,$- 35^{\star \star}$ &, $11^{*}$ &, $21^{\star *}$ & - & & \\
\hline 8 & 5,96 &, 75 &, $24^{* \star}$ &, $20^{\star \star}$ &, $25^{\star \star}$ &,$- \mathbf{4 3}^{\star \star}$ &, $29^{\star *}$ &, $\mathbf{4 2} 2^{* \star}$ &, $40^{* \star}$ & - & \\
\hline 9 & 5,51 & 1,20 &, $67^{\star *}$ &, $52^{\star \star *}$ &, $59^{\star *}$ &,- 08 &, 06 &,- 01 &, $17^{* *}$ &, $24^{* *}$ & - \\
\hline
\end{tabular}


Tablo 3: Liderden Tatmin Üzerinde Bağımsız Değişkenlerin Etkisini Gösteren Hiyerarşik Regresyon Analizi Sonuçları $(\mathrm{N}=390)$

\begin{tabular}{|c|c|c|c|c|c|c|}
\hline \multirow{3}{*}{ Değișkenler } & \multicolumn{6}{|c|}{ Liderden Tatmin } \\
\hline & \multicolumn{3}{|c|}{ Model-1 } & \multicolumn{3}{|c|}{ Model-2 } \\
\hline & $\mathbf{B}$ & S.H. & $\beta$ & B & S.H. & $\beta$ \\
\hline Sabit & 5,644 & .490 & & 2,096 & ,434 & \\
\hline Hizmet Y1li &, 031 &, 018 & ,167 &, 028 &, 013 &, $148^{*}$ \\
\hline Amirle Çalışma &,- 003 &, 066 &,- 002 &,- 040 &, 048 &,- 032 \\
\hline Yaş &,- 013 &, 019 &,- 063 &,- 029 &, 014 &,$- 140^{\circ}$ \\
\hline Ön lisans &, 338 & ,179 & ,101 &, 142 & ,133 & ,042 \\
\hline Lisans &, 015 &, 168 &, 006 &,- 088 &, 124 &,- 032 \\
\hline Lisansüstü &,- 555 &, 378 &,- 076 &,- 283 & 279 &,- 039 \\
\hline Asta Yönelik İlgi & & & & 489 &, 058 & $.507^{\circ 4 *}$ \\
\hline İşe Yönelik İlgi & & & & .043 & 061 & 040 \\
\hline Farkındalık & & & &, 227 & ,075 & $186^{* *}$ \\
\hline $\mathbf{R}$ & & .178 & & & .697 & \\
\hline $\mathbf{R}^{2}$ & & .032 & & & .486 & \\
\hline$\Delta \mathbf{R}^{2}$ & & .032 & & & .454 & \\
\hline Düz. $\mathbf{R}^{2}$ & & .017 & & & .474 & \\
\hline
\end{tabular}

edilmesini müteakiben regresyona sokulmasını ve raporlamada beta değeri $(\beta)$ yerine düzeltilmemiş beta (B) değerinin belirtilmesi gerektiğini önermektedirler. $\mathrm{Bu}$ bağlamda öncelikle kontrol değişkenleri standardize edilerek birinci aşamada regresyona sokulmuş; müteakiben bağımsız değişkenlerle, düzenleyici değişken olarak alınan kişilik özellikleri standardize edilerek ikinci aşamada regresyona sokulmuş; son olarak standardize edilen değişkenlerin birlikte etkileşimleri (çarpımları) üçüncü aşamada regresyona dâhil edilmiştir. Analiz kapsamında oluşturulan modellerde çoklu doğrusal bağlantı sorunu olup olmadığını belirlemek maksadıyla doğrudaşlık/eş doğrusallık (collinearity) değerlerine de bakılmıştır. Elde edilen tolerans ve VIF değerleri (Tolerans=1/VIF, Tolerans $>1-\mathrm{R}^{2}$ ) bağımsız değişkenler arası çoklu doğrusal bağlantı olmadığını ve standardize edilmemiş katsayıların (Unstandardized Coefficients) regresyon modeline ait denklemlerde kullanılabileceğini göstermiştir (Gürbüz \& Şahin, 2014).

Kişilik özelliklerinin, asta yönelik ilgi ve liderden tatmin ilişkisinde düzenleyici bir rolünün olup olmadığını tespit etmek maksadıyla yapılan düzenleyici değişkenli çoklu hiyerarşik regresyon analizi sonucu Tablo 4'te gösterilmiştir. Tablo4'teki bulgular, ilk aşamada analize dâhil edilen kontrol değişkenlerinin liderden tatmine anlamlı bir katkısının bulunmadığını $\left(\mathrm{R}^{2}=, 032 ; \mathrm{p}>0.05\right)$ göstermiştir. İkinci aşamada analize dâhil edilen bağımsız değişkenlerin liderden tatmin üzerinde anlamlı katkısının bulunduğu $\left(\Delta \mathrm{R}^{2}=, 452 ; \mathrm{p}<0.001\right)$ ve açıklanan varyansı \%48,4'e çıkardığı; bu aşamada hizmet yılı, gelişime açıklık, özdisiplin ve asta yönelik ilginin (sırasıyla $\mathrm{B}=, 185$; $\mathrm{p}<0.05$; $\mathrm{B}=$ -
,136; $\mathrm{p}<0.05 ; \mathrm{B}=, 152 ; \mathrm{p}<0.01$ ve $\mathrm{B}=, 782$; $\mathrm{p}<0.001$ ) liderden tatmin üzerinde anlaml katkısının bulunduğu görülmüştür. Üçüncü aşamada hizmet yılı, gelişime açıklık, özdisiplin ve asta yönelik ilgi ile birlikte analize dâhil edilen asta yönelik ilgi ile gelişime açıklığın etkileşimsel etkisinin liderden tatmin üzerinde anlamlı katkısının (sirasiyla $\mathrm{B}=, 185 ; \mathrm{p}<0.05 ; \mathrm{B}=-, 149 ; \mathrm{p}<0.05 ; \mathrm{B}=$ ,160; $\mathrm{p}<0.01 ; \mathrm{B}=, 783, \mathrm{p}<0.001$ ve $\mathrm{B}=, 163$, $\mathrm{p}<0.01) \quad$ bulunduğu $\left(\Delta \mathrm{R}^{2}=\quad, 018 ; \quad \mathrm{p}<0.05\right)$ görülmüştür. Toplam açıklanan varyans $\% 50,2$ ve düzeltilmiş $\mathrm{R}^{2}$ değeri ,479 olarak tespit edilmiştir. Dolayısıyla asta yönelik ilgi ile astların liderden tatmini arasında gelişime açıklığın düzenleyici bir rolünün bulunduğu tespit edilmiştir.

Her ne kadar regresyon katsayıları etki büyüklüğünü gösteren istatistikler olsa da, düzenleyici model analizinde etki büyüklüğünün (effect size) hesaplanmasinda Cohen'in $\mathrm{f}^{2}=\left(\mathrm{r}_{2}{ }^{2}\right.$ $\left.\mathrm{r}_{1}{ }^{2}\right) /\left(1-\mathrm{r}_{1}{ }^{2}\right)$ formülünün kullanılması önerilmektedir (Aiken \& West, 1991). Bu denklemde $\mathrm{r}_{1}^{2}$, hiyerarşik regresyon analizinde ikinci adıma ait $\mathrm{R}$ kare ( $\mathrm{R}$ square); $\mathrm{r}_{2}{ }^{2}$ ise üçüncü adıma ait $\mathrm{R}$ kare değeridir. Tablo 4'te yer alan değerlere göre $f^{2}=$ $((0,502-0,484) /(1-0,484))=0,035$ 'tir. $\quad \mathrm{Bu}$ değer bağımlı değişkende açıklanmayan varyansa göre, düzenleyicilik tarafından açıklanan sistematik varyans oranını göstermektedir (Gürbüz \& Şahin, 2014). Cohen, Cohen, Aiken ve West'e (2003)göre $f^{2}=0,02$ ise düşük etki; $f^{2}=0,15$ ise orta etki; $f^{2}=$ 0,26 ise büyük etki söz konusudur. Aiken ve West'in (1991: 157) önerileri doğrultusunda, asta yönelik ilgi ile gelişime açıklığın etkileşiminin çarpımsal sonucunun etki büyüklüğü $f^{2}=0,03$ olarak hesaplanmış ve etki büyüklüğünün düşük düzeyde olduğu görülmüştür. $\mathrm{Bu}$ etki büyüklüğü, 
Tablo 4: Asta Yönelik İlgi - Amirden Tatmin İlişkisinde Kişilik Özelliklerinin Düzenleyici Rolüne İlişkin Düzenleyici Değişkenli Çoklu Hiyerarşik Regresyon Analizi Sonucu ( $N=390)$

\begin{tabular}{|c|c|c|c|c|c|c|c|c|c|}
\hline \multirow{3}{*}{ Değișkenler } & \multicolumn{9}{|c|}{ Liderden Tatmin } \\
\hline & \multicolumn{3}{|c|}{ Model-1 } & \multicolumn{3}{|c|}{ Model-2 } & \multicolumn{3}{|c|}{ Model-3 } \\
\hline & B & S.H. & $\beta$ & $\mathbf{B}$ & S.H. & $\beta$ & $\mathbf{B}$ & S.H. & $\beta$ \\
\hline Sabit & 5,514 & 061 & & 5,505 &, 045 & & 5,494 &, 046 & \\
\hline Hizmet Yili & ,202 &, 114 &, 167 &, $185^{*}$ &, 084 &, 153 &, $185^{*}$ &, 083 &, 154 \\
\hline Amirle Çalışma &,- 003 &, 063 &,- 002 &,- 045 &, 047 &,- 038 &,- 060 &, 047 &,- 050 \\
\hline Yaş &,- 077 &, 110 &,- 063 &,- 158 &, 082 &,- 131 &,$- 165^{\circ}$ &, 081 &,- 137 \\
\hline Ön Lisans &, 122 &, 065 &, 101 &, 044 &, 048 &, 036 &, 023 &, 048 &, 019 \\
\hline Lisans &, 007 &, 073 &, 006 &,- 033 &, 054 &,- 027 &,- 029 &, 054 &,- 024 \\
\hline Lisansüstü &,- 092 &, 063 &,- 076 &,- 045 &, 047 &,- 038 &,- 046 &, 046 &,- 039 \\
\hline Nevrotiklik & & & &, 045 &, 055 &, 037 &, 068 &, 055 &, 057 \\
\hline Dişadönüklük & & & &, 058 &, 056 &, 048 &, 071 &, 057 &, 059 \\
\hline Gelişime Açıklik & & & &,$- 136^{\circ}$ &, 055 &,- 112 &,$- 149^{*+}$ &, 055 &,- 123 \\
\hline Uyumluluk & & & &, 037 &, 051 &, 031 &, 050 &, 051 &, 041 \\
\hline Özdisiplin & & & &, $152^{* *}$ &, 057 &, 126 &, $160^{\circ 4}$ &, 056 & 132 \\
\hline Asta Yönelik İlgi & & & &, $782^{4+4}$ &, 048 &, 643 &, $783^{4+0}$ &, 048 &, 644 \\
\hline $\begin{array}{l}\text { Asta Yönelik İlgi X } \\
\text { Nevrotiklik }\end{array}$ & & & & & & &,- 073 &, 063 &,- 056 \\
\hline $\begin{array}{l}\text { Asta Yönelik İlgi X } \\
\text { Disadönüiklük }\end{array}$ & & & & & & &,- 070 &, 065 &,- 050 \\
\hline $\begin{array}{l}\text { Asta Yönelik İlgi X } \\
\text { Gelişime Açıklık }\end{array}$ & & & & & & &, $163^{* *}$ &, 052 &, 141 \\
\hline $\begin{array}{l}\text { Asta Yönelik İlgi X } \\
\text { Uyumluluk }\end{array}$ & & & & & & &, 023 &, 050 &, 019 \\
\hline $\begin{array}{l}\text { Asta Yönelik İlgi X } \\
\text { Özdisiplin }\end{array}$ & & & & & & &,- 021 &, 057 &,- 018 \\
\hline $\mathbf{R}$ & & .178 & & & .696 & & & .708 & \\
\hline $\mathbf{R}^{2}$ & & .032 & & & .484 & & & .502 & \\
\hline$\Delta \mathbf{R}^{2}$ & & .032 & & & .452 & & & .018 & \\
\hline Düz. $\mathbf{R}^{2}$ & & .017 & & & .468 & & & .479 & \\
\hline
\end{tabular}

değer olarak küçük olmakla birlikte, deneysel olmayan çalışmalardan elde edilen sonuçlar arasinda ( .01 - .03 aras1) kabul edilebilir düzeydedir (Chaplin, 1991).
Aradaki etkileşimi analiz etmek maksadıyla eğim testi (simple slope) analizi yapılmıştır (Aiken \& West, 1991). Eğim testi grafiği Şekil 1'de gösterilmiştir.

Şekil 1: Asta Yönelik İlgi ile Liderden Tatmin Arasındaki İlişkide Gelişime Açıklığın Düzenleyici Rolü

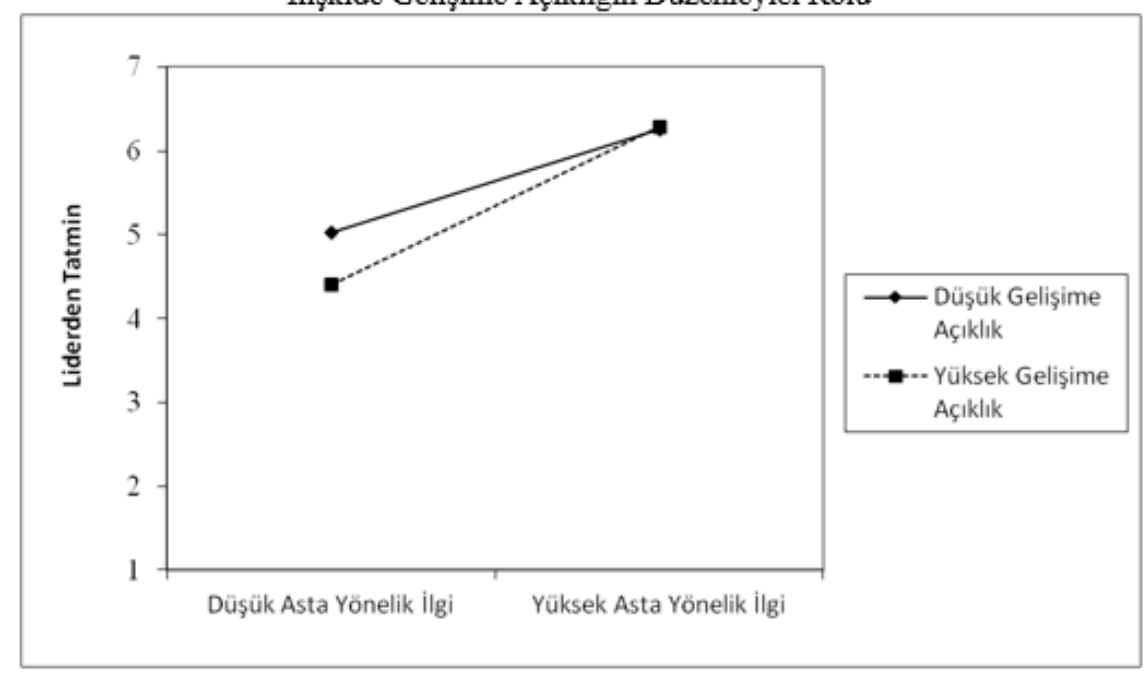


Eğim testi analizi sonucunda; astların gelişime açıklığı düşük olduğunda (ortalamanın 1 standart sapma altında) liderlerin asta yönelik ilgilerinin pozitif yönde ve anlamlı olarak astların liderden tatminini etkilediği $(B=, 690 ; t=10.979 ; \mathrm{p}<0.01)$; astların gelişime açıklığı yüksek olduğunda ise (ortalamanın 1 standart sapma üzerinde) liderlerin asta yönelik ilgilerinin pozitif yönde ve anlamlı olarak astların liderden tatminini daha fazla etkilediği $\quad(\mathrm{B}=\quad, 958 ; \quad \mathrm{t}=15,007 ; \quad \mathrm{p}<0.01)$ görülmüştür. $\mathrm{Bu}$ durum bize gelişime açıklığın yüksek olduğu düzeyde liderlerin asta yönelik ilgileri ile astların liderden tatmini arasında daha kuvvetli bir ilişki olduğunu göstermektedir.

Kişilik özelliklerinin, işe yönelik ilgi ve liderden tatmin ilişkisinde düzenleyici bir rolünün olup olmadığını tespit etmek maksadıyla yapılan düzenleyici değişkenli çoklu hiyerarşik regresyon analizi sonucu Tablo 5'te gösterilmiştir. Tablo 5 'teki bulgular, ilk aşamada analize dâhil edilen kontrol değişkenlerinin liderden tatmine anlamlı bir katkısının bulunmadığını $\left(\mathrm{R}^{2}=, 032 ; \mathrm{p}>0.05\right)$ göstermiştir.

İkinci aşamada analize dâhil edilen bağımsız değişkenlerin (işe yönelik ilgi ve beş kişilik özelliği) liderden tatmin üzerinde anlamlı katkısının bulunduğu $\left(\Delta \mathrm{R}^{2}=, 288 ; \mathrm{p}<0.001\right)$ ve açıllanan varyansı \%32'ye çıkardığı; bu aşamada lisans üstü eğitim, özdisiplin ve işe yönelik ilginin (sırasıyla $\mathrm{B}=-, 112 ; \mathrm{p}<0.05 ; \mathrm{B}=, 215 ; \mathrm{p}<0.01$ ve $\mathrm{B}=, 582$; $\mathrm{p}<0.001)$ liderden tatmin üzerinde anlamlı katkısının bulunduğu görülmüştür. Üçüncü aşamada lisans üstü eğitim, özdisiplin ve işe yönelik ilginin (sırasiyla $\mathrm{B}=-, 117 ; \mathrm{p}<0.05 ; \mathrm{B}=, 222 ; \mathrm{p}<0.01$ ve $\mathrm{B}=$ ,593; $\mathrm{p}<0.001)$ liderden tatmin üzerinde anlamlı katkısı bulunmakla birlikte, analize dâhil edilen işe yönelik ilgi ile kişilik özelliklerinin etkileşimsel etkilerinin liderden tatmin üzerinde anlamlı katkısının bulunmadığı $\left(\Delta \mathrm{R}^{2}=\quad, 012 ; \quad \mathrm{p}>0.05\right)$ görülmüştür. Toplam açıklanan varyans $\% 33,2$ ve düzeltilmiş $\mathrm{R}^{2}$ değeri ,301 olarak tespit edilmiştir. Dolayısıyla işe yönelik ilgi ile liderden tatmin arasında kişiliğin düzenleyici bir rolünün bulunmadığı tespit edilmiştir.

Kişilik özelliklerinin, farkındalık ve liderden tatmin ilişkisinde düzenleyici bir rolünün olup olmadığını tespit etmek maksadıyla yapılan düzenleyici değişkenli çoklu hiyerarşik regresyon analizi sonucu Tablo 6'da gösterilmiştir. Tablo 6'daki

Tablo 5: İşe Yönelik İlgi - Amirden Tatmin İlişkisinde Kişilik Özelliklerinin Düzenleyici Rolüne İlişkin Düzenleyici Değişkenli Çoklu Hiyerarşik Regresyon Analizi Sonucu

\begin{tabular}{|c|c|c|c|c|c|c|c|c|c|}
\hline \multirow{3}{*}{ Değișkenler } & \multicolumn{9}{|c|}{ Liderden Tatmin } \\
\hline & \multicolumn{3}{|c|}{ Model-1 } & \multicolumn{3}{|c|}{ Model-2 } & \multicolumn{3}{|c|}{ Model-3 } \\
\hline & $\mathbf{B}$ & S.H. & $\beta$ & $\mathbf{B}$ & S.H. & $\beta$ & $\mathbf{B}$ & S.H. & $\beta$ \\
\hline Sabit & 5,514 &, 061 & & 5,510 &, 051 & & 5,492 &, 054 & \\
\hline Hizmet Yilı & 202 &, 114 &, 167 &, 172 &, 096 &, 142 &, 175 &, 096 &, 145 \\
\hline Amirle Çalışma &,- 003 &, 063 &,- 002 &,- 022 &, 054 &,- 018 &,- 037 &, 054 &,- 030 \\
\hline Yaş &,- 077 &, 110 &,- 063 &,- 122 &, 094 &,- 101 &,- 126 &, 094 &,- 104 \\
\hline Ön Lisans &, 122 &, 065 & 101 &, 053 &, 055 &, 044 &, 054 &, 055 &, 044 \\
\hline Lisans &, 007 &, 073 &, 006 &,- 042 &, 062 &,- 035 &,- 038 &, 062 &,- 031 \\
\hline Lisans Üstü &,- 092 &, 063 &,- 076 &,$- 112^{*}$ &, 054 &,- 093 &,$- 117^{*}$ &, 054 &,- 097 \\
\hline Nevrotiklik & & & &, 018 &, 063 &, 015 &, 016 &, 064 &, 014 \\
\hline D1şadönüklük & & & &, 044 &, 065 &, 036 &, 049 &, 066 &, 040 \\
\hline Gelişime Açıklık & & & &,- 120 &, 064 &,- 099 &,- 125 &, 064 &,- 103 \\
\hline Uyumluluk & & & &, 026 &, 059 &, 021 &, 020 &, 059 &, 017 \\
\hline Özdisiplin & & & &, $215^{\circ *}$ &, 065 &, 177 &, $222^{* 4}$ &, 065 &, 183 \\
\hline İşe Yönelik İlgi & & & &, $582^{4 * 4}$ &, 055 & 481 &, $593^{* 0 *}$ &, 057 & ,490 \\
\hline $\begin{array}{l}\text { İse Yönelik Îlgi X } \\
\text { Nevrotiklik }\end{array}$ & & & & & & &, 033 &, 077 &, 026 \\
\hline $\begin{array}{l}\text { İşe Yönelik İlgi X } \\
\text { D1şadönüklük }\end{array}$ & & & & & & &,- 038 &, 077 &,- 028 \\
\hline $\begin{array}{l}\text { İşe Yönelik İlgi X } \\
\text { Gelişime Açıklik }\end{array}$ & & & & & & &, 104 &, 060 &, 090 \\
\hline $\begin{array}{l}\text { İşe Yönelik İlgi X } \\
\text { Uyumluluk }\end{array}$ & & & & & & & 091 &, 066 &, 074 \\
\hline $\begin{array}{l}\text { İşe Yönelik İlgi X } \\
\text { Özdisiplin }\end{array}$ & & & & & & &, 006 &, 063 &, 005 \\
\hline $\mathbf{R}$ & & .178 & & & .566 & & & .576 & \\
\hline $\mathbf{R}^{2}$ & & .032 & & & .320 & & & .332 & \\
\hline$\Delta \mathbf{R}^{2}$ & & .032 & & & .288 & & & .012 & \\
\hline Düz. $\mathbf{R}^{2}$ & & .017 & & & .298 & & & .301 & \\
\hline
\end{tabular}


Tablo 6: Farkındalık - Liderden Tatmin İlişkisinde Kişilik Özelliklerinin Düzenleyici Rolüne İlişkin Düzenleyici Değişkenli Çoklu Hiyerarşik Regresyon Analizi Sonucu

\begin{tabular}{|c|c|c|c|c|c|c|c|c|c|c|}
\hline \multirow{3}{*}{ Değișkenler } & & \multicolumn{9}{|c|}{ Amirden Tatmin } \\
\hline & & \multicolumn{3}{|c|}{ Model-1 } & \multicolumn{3}{|c|}{ Model-2 } & \multicolumn{3}{|c|}{ Model-3 } \\
\hline & & B & S.H. & $\beta$ & B & S.H. & $\beta$ & B & S.H. & ; \\
\hline Sabit & & 5,514 & 061 & & 5,506 & .049 & & 5,484 & .050 & \\
\hline Hizmet Y1li & &, 202 &, 114 & 167 &, 156 & 091 & 129 &, 152 & 091 &, 126 \\
\hline Amirle Çalışma & &,- 003 &, 063 &,- 002 &,- 072 &, 051 &,- 060 &,- 081 &, 051 &,- 067 \\
\hline Yaş & &,- 077 &, 110 &,- 063 &,- 147 & .089 &,- 122 &,- 145 &, 088 &,- 120 \\
\hline Ön Lisans & &, 122 &, 065 &, 101 & $109^{\circ}$ &, 052 &, 090 &, 092 &, 052 &, 076 \\
\hline Lisans & &, 007 &, 073 &, 006 &,- 007 & 059 &,- 006 &, 001 &, 058 &, 001 \\
\hline Lisans Üstü & &,- 092 &, 063 &,- 076 &,- 058 &, 051 &,- 048 &,- 062 &, 051 &,- 051 \\
\hline Nevrotiklik & & & & &, 029 &, 060 &, 024 &, 036 &, 061 &, 030 \\
\hline D1şadönüklük & & & & &, 041 &, 061 &, 034 &, 068 &, 063 &, 056 \\
\hline Gelişime Açıklık & & & & &,$- 154^{*}$ &, 060 &,- 127 &,$- 172^{* *}$ &, 060 &,- 142 \\
\hline Uyumluluk & & & & &,- 007 &, 056 &,- 006 &,- 009 &, 056 &,- 008 \\
\hline Özdisiplin & & & & &, $197^{* *}$ &, 061 &, 162 & $208^{4 *}$ &, 061 & 171 \\
\hline Farkındalik & & & & &, $687^{* 0 *}$ &, 053 & ,563 &, $686^{\circ 04}$ &, 054 & ,563 \\
\hline $\begin{array}{l}\text { Farkındalik } \\
\text { Nevrotiklik }\end{array}$ & $\mathrm{X}$ & & & & & & &,- 021 &, 070 &,- 018 \\
\hline $\begin{array}{l}\text { Farkındalık } \\
\text { Dışadönüklük }\end{array}$ & $\mathrm{X}$ & & & & & & &,- 088 &, 072 &,- 067 \\
\hline $\begin{array}{l}\text { Farkındalık } \\
\text { Gelişime Açıklık }\end{array}$ & $\mathrm{X}$ & & & & & & &, $163^{4 *}$ &, 060 &, 142 \\
\hline $\begin{array}{l}\text { Farkindalik } \\
\text { Uyumluluk }\end{array}$ & $\mathrm{X}$ & & & & & & &, 075 &, 055 &, 070 \\
\hline $\begin{array}{l}\text { Farkındalık } \\
\text { Özdisiplin }\end{array}$ & $\mathrm{X}$ & & & & & & &,- 018 &, 062 &,- 016 \\
\hline $\mathbf{R}$ & & & .178 & & & .625 & & & .640 & \\
\hline $\mathbf{R}^{2}$ & & & .032 & & & .391 & & & .410 & \\
\hline$\Delta \mathbf{R}^{2}$ & & & .032 & & & .359 & & & .019 & \\
\hline Düz. $\mathbf{R}^{2}$ & & & .017 & & & .371 & & & .383 & \\
\hline
\end{tabular}

bulgular, ilk aşamada analize dâhil edilen kontrol değişkenlerinin liderden tatmine anlamlı bir katkısının bulunmadı̆̆ını $\left(\mathrm{R}^{2}=, 032 ; \mathrm{p}>0.05\right)$ göstermiştir. İkinci aşamada analize dâhil edilen bağımsız değişkenlerin (farkındalık ve beş kişilik özelliği) liderden tatmin üzerinde anlamlı katkısının bulunduğu $\left(\Delta \mathrm{R}^{2}=, 359 ; \mathrm{p}<0.001\right)$ ve açıklanan varyansı \%39,1'e çıkardığı; bu aşamada ön lisans, gelişime açıklık, özdisiplin ve farkındalığın (sirasiyla $\mathrm{B}=, 109 ; \mathrm{p}<0.05 ; \mathrm{B}=-, 154 ; \mathrm{p}<0.05 ; \mathrm{B}=$ ,197; $\mathrm{p}<0.01$ ve $\mathrm{B}=, 687 ; \mathrm{p}<0.001)$ liderden tatmin üzerinde anlamlı katkısının bulunduğu görülmüştür. Üçüncü aşamada gelişime açıklık, özdisiplin ve farkındalık ile birlikte analize dâhil edilen farkındalık ile kişilik özelliklerinden gelişime açıklığın etkileşimsel etkisinin liderden tatmin üzerinde anlamlı katkısının (sırasıyla $\mathrm{B}=-, 172$; $\mathrm{p}<0.01 ; \mathrm{B}=, 208 ; \mathrm{p}<0.01 ; \mathrm{B}=, 686, \mathrm{p}<0.001$ ve $\mathrm{B}=$ ,163, $\mathrm{p}<0.01)$ bulunduğu $\left(\Delta \mathrm{R}^{2}=, 019 ; \mathrm{p}<0.05\right)$ görülmüştür. Toplam açılklanan varyans $\% 41$ ve düzeltilmiş $\mathrm{R}^{2}$ değeri ,383 olarak tespit edilmiştir. Dolayısıyla farkındalık ile astların liderden tatmini arasında gelişime açıklığın düzenleyici bir rolünün bulunduğu tespit edilmiştir.
Tablo 6'da yer alan değerlere göre, farkındalık ile gelişime açıklığı etkileşiminin çarpımsal sonucunun etki genişliği $f^{2}=((0,410-0,391) /(1-$ $0,391)=0,031$ olarak hesaplanmış ve etki büyüklüğünün düşük düzeyde olduğu görülmüştür.

Aradaki etkileşimi analiz etmek maksadıyla eğim testi analizi yapılmıştır (Aiken \& West, 1991). Eğim testi grafiği Şekil 2'de gösterilmiştir.

Eğim testi sonucunda; astların gelişime açıklığ düşük olduğunda (ortalamanın 1 standart sapma altında) liderlerin farkındalığının pozitif yönde ve anlamlı olarak astların liderden tatminini etkilediği $(\mathrm{B}=, 605 ; \mathrm{t}=8,572 ; \mathrm{p}<0.01)$; astların gelişime açıklığı yüksek olduğunda ise (ortalamanın 1 standart sapma üzerinde) liderlerin farkındalığının pozitif yönde ve anlamlı olarak astların liderden tatminini daha fazla etkilediği $(B=, 840 ; t=12,342$; $\mathrm{p}<0.01)$ tespit edilmiştir. $\mathrm{Bu}$ durum bize gelişime açıklığın yüksek olduğu düzeyde liderlerin farkındalı̆ $\breve{1}_{1}$ ile astların liderden tatmini arasında kuvvetli bir ilişki olduğunu göstermektedir. 
Șekil 2: Farkındalik ile Liderden Tatmin Arasında Gelişime Açıklığın Düzenleyici Rolü

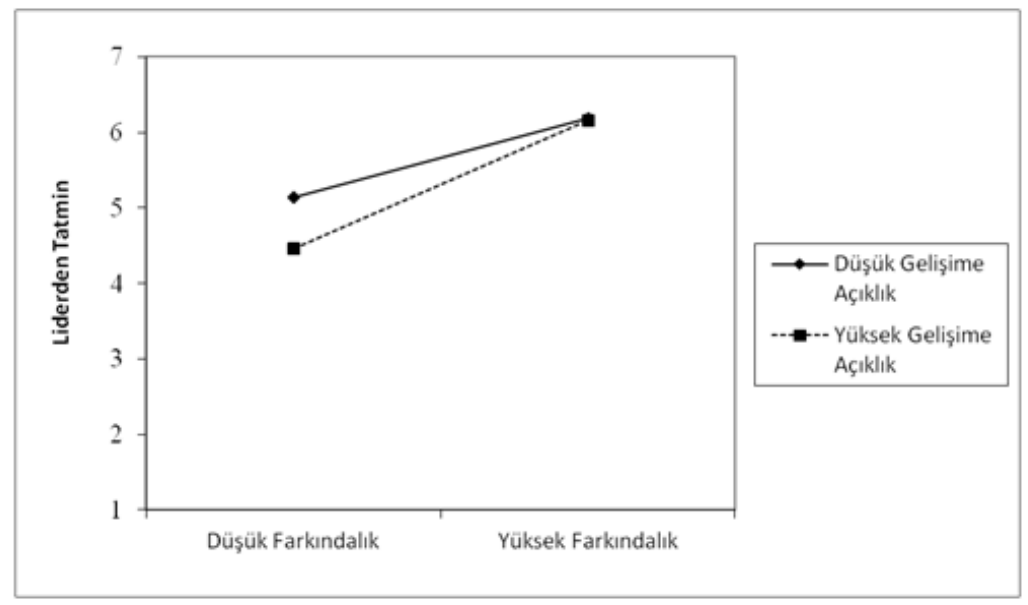

Yapılan düzenleyici değişkenli çoklu hiyerarşik regresyon analizi sonucunda askeri liderlikle astların liderden tatminleri arasında astların kişilik özelliklerinin kısmen (asta yönelik ilgi ve farkındalık boyutlarında gelişime açıklığın) düzenleyici rolünün bulunduğu tespit edilmiştir. Dolayısıyla ikinci hipotez "kısmen" desteklenmiştir.

\section{TARTIŞMA}

$\mathrm{Bu}$ çalışmanın amacı, askeri liderlikle astların liderden tatmini arasındaki ilişkiyi incelemek ve bu ilişkide astların kişilik özelliklerinin düzenleyici rolünü ortaya koymaktır. $\mathrm{Bu}$ maksatla savunma sanayinden bir kurumda görev yapan 390 örneklem üzerinde araştırma yapılmıştır.

Araştırmaya katılanların yaş ortalaması 30,08 (s.s.=5.99), mesleki deneyim ortalaması 7,49 (s.s. $=6,93)$, amirleriyle birlikte çalışma süresi ortalamas1 1,78 (s.s.=1,04) yıldır. Katılımcılar, liderlerinin farkındalık ve işe yönelik ilgilerini asta yönelik ilgilerine oranla daha yüksek olarak algilamaktadırlar (sirasiyla ortalamalar; 5.79; 5.74; 5.32). Savunma sektöründeki hiyerarşik yapılanma, katı disiplin anlayışı, belirsizlik durumlarına karşı çevrenin izlenerek gerekli değişikliklerin yapılması ve farklı koşullara yönelik hazırlıklı olunması göz önüne alınırsa, önceliğin göreve ve farkındalığa verilmesi anlamlidir.

Korelasyon analizi sonucu askeri liderlikle liderden tatmin arasında pozitif yönde anlamlı bir ilişki bulunduğu görülmüştür. $\mathrm{Bu}$ bulgu bize liderlerin askeri liderlik tarzı arttıkça astların liderden duydukları tatminin de arttığını göstermektedir. Dolayısıyla askeri liderliğin astların liderden duydukları tatmin üzerindeki etkisini belirlemek maksadıyla regresyon analizi yapılmıştır.

Yapılan hiyerarşik doğrusal regresyon analizi sonucu; liderlerin asta yönelik ilgilerinin astların liderden tatminlerini $(\beta=, 507 ; \mathrm{p}<0.001)$ yüksek düzeyde, farkındalıklarının astların liderden tatminini $(\beta=, 186 ; p<0.01)$ orta düzeyde etkilediği tespit edilmiştir. $\mathrm{Bu}$ bulgu bize, astların liderden tatminleri üzerinde açıllanan varyansın \%50.7'sinin liderlerin asta yönelik ilgileri, \%18.6'sının farkındalıkları tarafından açıklandığını göstermektedir.

Asta yönelik ilginin liderden tatmini pozitif yönde etkilemesi yazınla (Dobbins \& Zaccaro, 1986; Künter, 2014; Vecchio, 1981) tutarlıdır. Künter (2014) de çalışmasında asta yönelik ilginin liderden tatmini anlamlı olarak yordadı $\breve{g}_{1}(\beta=, 762 ; \mathrm{p}<0.001)$ bulgusuna ulaşmıştır. Liderlerin astlarına bireysel ilgi gösterici davranışlarda bulunması, astların kendilerine değer verildiğini hissederek liderlerinden memnun olmalarına ve liderlerine pozitif bir tepki göstermelerine yol açabilir. Kaynakların Korunması Teorisi'ne göre astların, aradaki ilişkinin olumlu olması durumunda olumlu bir duygu içerisinde olacakları, daha az stres yaşayacakları, sahip oldukları kaynakları koruyacakları ve liderlerinden tatmin olacakları ifade edilebilir (Benoliel \& Somech, 2014).

Araştırmanın bir diğer bulgusu, farkındalık boyutunun liderden tatmin üzerindeki pozitif etkisidir. Astlar, liderlerinin farkındalığının yüksek olması durumunda; liderlerinin koşulları daha iyi anlayabileceklerini, kurumun çevreye uyumunu sağlayarak belirsizliği azaltabileceklerini ve gerekli değişiklikleri yapabileceklerini değerlendirerek liderlerinden memnun olmaktadırlar. Liderlerin 
farkındalık boyutunun yüksek olması kurumun devamlılığını güvence altına aldığından, kuruma da katkı sağlamaktadır. Künter (2014) de çalışmasında benzer sonuca $(\beta=, 081 ; \mathrm{p}<0.001)$ ulaşmıştır.

Araştırmanın amaçlarından bir diğeri, askeri liderlikle astların liderden tatmini arasındaki ilişkide astların kişilik özelliklerinin düzenleyici rolünü ortaya koymaktır. Bu maksatla yapılan düzenleyici değişkenli çoklu hiyerarşik regresyon analizi sonucunda; liderlerin asta yönelik ilgileri ve farkındalıkları ile astların liderden tatminleri arasında gelişime açıklığın düzenleyici rolü bulunduğu tespit edilmiştir.

Gelişime açıklık, yeni şeyler deneyimleme, yenilikleri takip etme, esneklik gibi kavramlarla ilişkilidir (Costa \& McCrae, 1992). Dolayısıyla gelişime açıklığı yüksek olan astlara, liderlerinin yüksek düzeyde asta yönelik liderlik tarzı sergilemeleri durumunda, astlar arzuladıkları esnekliği ve rahatlığ hoşnut olacaklardır. Böylece buna müsaade ettiğini düşündükleri liderlerinden duydukları tatmin de artacaktır. Ayrıca, gelişime açıklığı yüksek olan astlar, liderlerinin yüksek düzeyde farkındalık tarzını sergilemeleri durumunda, liderlerinin farkındalık düzeyinin yüksek olduğunu, çevreyi anlamak ve uyum sağlamak için yeniliklere açık olduğunu değerlendirecekler; liderleri ile uyum içinde çalışma firsatı yakalamaları nedeniyle liderlerinden duydukları tatmin de yüksek olacaktır. Kaynakların Korunması Teorisi bağlamında sahip olduğu kaynakları koruduğunu ve yeni kaynaklara sahip olma firsatı yakaladığını düşünen astların tatmini de yükselecektir.

Araştırmada astların kişilik özelliklerinden sadece gelişime açıklığın askeri liderlikle bağımlı değişkenler arasında düzenleyici rolünün bulunduğu tespit edilmiş; diğer kişilik özelliklerinin herhangi bir düzenleyici rolü tespit edilememiştir. Özellikle yazında kişilik özelliklerinden dışadönüklük ve özdisiplin boyutlarının farklı değişkenler arasındaki ilişkide düzenleyici rolünün bulunduğu (Benoliel \& Somech, 2014; Cicerali, 2012) belirtilmektedir. Dışadönükler, pozitif duygulara sahip olup, girişkenlik, sosyalleşme ve daha fazla arkadaş edinme arayışındadırlar (Costa \& McCrae, 1992; Watson \& Clark, 1997: 769). Özdisiplinli bireylerin de sorumluluk ve görev bilinci yüksektir. Bu özelliklerinin yüksek olması, bireylerin daha yüksek olumlu tutum ve davranış (performans, tatmin, bağlılık, vb.) içerisinde bulunmalarına yol açmaktadır. Dolayısıyla, özdisiplini ve dışadönüklük özellikleri yüksek olanların, amirlerinin liderlik tarzını yüksek olarak algıladıklarında tatminlerinin de yüksek olacağı bu çalışmada beklenen sonuçlar arasında olmakla birlikte, analizlerde bu sonuca ulaşılamamıştır. Bunun nedeni, askeri ortamlarda görev yapan astların dışadönüklük ve özdisiplinlerinin düşük ya da yüksek olması durumunda amirlerinin liderlik tarzını düşük ya da yüksek algılamalarının tatminlerini etkilemediğini değerlendirmeleri olabilir. Yazında gelişime açıklığın düzenleyici rolüne yönelik herhangi bir çalışma tespit edilememiştir. Dolayısıyla, bu çalışmanın gelişime açıklığın düzenleyici rolünü ortaya koyan ender çalışmalardan birisi olduğu değerlendirilmektedir.

\subsection{Araștırmanın Kuvvetli ve Zayıf Tarafları}

Yapılan çalışmanın bazı kuvvetli tarafları bulunmaktadır. İlişsisel Liderlik Teorisyenleri (ör. Brower, Schoorman \& Tan, 2000 Uhl-Bien, 2006) liderle astları arasında geliştirilen ilişkinin, astların çıktıları için önemli olduğunu; bu nedenle sadece lider, ast ya da koşulların liderlik çıktısını açıklamada yetersiz kaldığını ifade etmektedirler. $\mathrm{Bu}$ araştırmada ortak yöntem varyansını azaltmak için; bağımsız ve düzenleyici değişken verileri ilk safhada, bağımlı değişken verileri bir ay sonra ikinci safhada toplanmıştır. Çalışmanın en kuvvetli taraflarından birisi budur.

Yazında sadece iki değişken arasında neden-sonuç ilişkisini inceleyen çalışmalar yetersiz görülmekte, değişkenlerin aracılık ve düzenleyicilik etkilerine de odaklanılması gerektiği vurgulanmaktadır. $\mathrm{Bu}$ araştırmada da askeri liderlikle astların tutumları arasındaki ilişkide astların kişilik özelliklerinin düzenleyici rolü incelenmiştir.

Regresyon analizlerinde demografik veri değişkenleri (yaş, hizmet yılı, liderle çalışma süresi ve eğitim) ilk safhada regresyon analizine dâhil edilerek kontrol altına alınmış, askeri liderliğin boyutları ikinci safhada analize dâhil edilmiştir. Böylece askeri liderliğin astların liderden duydukları tatmin üzerindeki etki ortaya konulmuştur.

\subsection{Teorik ve Uygulamaya Katkısı}

Teorik açıdan bu araştırma, amirlerin liderlik tarzlarının astların amirden tatmini üzerindeki etkisini ve bu etkide astların kişilik özelliklerinin düzenleyici rolünü göstermektedir.

Araştırmada ulaşılan bulgular, Hobfoll'un (1989, 2001) Kaynakların Korunması Teorisi'ne katk1 yapmaktadır. Hobfoll ve Shirom (2001) Kaynakların Korunması Teorisi'nin, bireylerin kayıplarla nasıl mücadele ettiği ve kaynakları nasıl kullandığını etkilemesi nedeni ile kişisel özellikleri kaynak olarak ele aldığını öne sürmektedir. Bu bağlamda araştırmada ulaşılan sonuçların, astların 
strese karşı dayanıklılığını artıran bir faktör olan kişisel özelliklerden bazılarının, savunma alanında kaynakları elde etme ve korumasında kişisel kaynak olarak görülerek ve içinde bulundukları koşullara uyum sağlamasını kolaylaştırarak, liderden tatminlerini etkileyeceğini göstermesi nedeni ile teoriye katkı yaptığ

Somut olarak, gelişime açıklığı yüksek olan astlar, liderlerinin asta yönelik ilgileri ve farkındalıklarını yüksek olarak algıladıklarında, liderlerinden daha fazla tatmin duymaktadırlar. $\mathrm{Bu}$ astlara göre; liderlerinin astlarını dikkate alması, astlarının sorunlarıyla ilgilenmesi, astlarına karşı adil olması ya da etrafta olup bitenlerin farkında olarak uyum sağlamas1, yetenek, özyeterlilik ya da liderleriyle sağlıklı iletişim kurma gibi kaynakları başarmak için birer firsat olarak görülmektedir. Bu nedenle asta yönelik ilgisi ve farkındalığı yüksek olan liderler, astlarının kaynak elde etmesine ve kendilerinden tatmin olmasına yol açabilir.

Geliştirilen liderlik ölçekleri, personel seçimi ve işe yerleştirmeden, performans değerlendirme ve terfiye kadar birçok İKY uygulamasında dikkate alınarak kullanılmaktadır (Bass, 1990). Dolayısıyla, yeni geliştirilmiş olan askeri liderlik ölçeğinin de savunma sanayinde personel seçimi, performans değerlendirme ve terfi alanlarında kullanılabileceği değerlendirilmektedir. Ayrıca, Bauer ve Green'in (1996) liderle astları arasında kaliteli bir ilişki geliştirmede kişilik benzerliğinin etkili olabileceği önerisinden hareketle, savunma alanında geleceğin lider kadrolarının seçiminde beş faktör kişilik özellikleri ölçeğinin uygulanarak, sonuçlarının dikkate alınmasının faydalı olacağı değerlendirilmektedir.

Yönetim alanında üst kademelere personel seçiminde bu ölçeğin kullanılması, astlarına değer veren, onlarla yakın bir iletişim kurabilen, aynı zamanda gelişen durumların farkında olarak uyum sağlayabilen ve görevin tam olarak yerine getirilmesini sağlayan liderlerin karar verici mercilerde bulunmasını ve kurumun etkinliğinin artırılmasını sağlayabilir.

\subsection{Araştırmanın Kısıtları ve Gelecek Araştırmalara Öneriler}

$\mathrm{Bu}$ araștırmada örneklemden kaynaklanan bulguların genellenebilirliği gibi kısıtlar nedeniyle değişkenler arasındaki ilişkiler ve neden-sonuç ilişkisinin dikkatle yorumlanması gerekir. Ayrıca, araştırma deneysel bir tasarıma sahip olmadığından, nedensellik sonuçları kısıtlıdır.

Kesitsel bir araştırma olması, çalışmanın en zayıf tarafıdır. Esasen liderlik yazınında yapılan çalışmaların çoğu (ör. Barrick \& Mount, 1991; Benoliel \& Somech, 2014; Costa \& McCrae, 1980; Judge, vd., 2004) kesitsel tasarıma sahiptir. Gerçekte, kesitsel korelasyonel tasarım nedenselliği önlemektedir (Dulebohn, Bommer, Liden, Brouer, \& Ferris, 2011). Yöntem varyansının doğrusal etkinin şiddetini artırabilmesi nedeniyle, gerçek etkiyi ortaya çıkarmak için sosyal bilim araştırmalarında az kullanılan "etkileşimsel etki”ye odaklanmak gerekmektedir (Şahin, 2011). Bu çalışmada etkileşimsel etkiye odaklanılarak, bu zayıflık azaltılmaya çalışılmıştır. Ayrıca, Gerstner ve Day (1997) ve Podsakoff, MacKenzie, Lee ve Podsakoff (2003) lider ve astları arasındaki ilişkiyi tam olarak anlamak için boylamsal çalışma yapmayı önermektedirler. Boylamsal çalışmaya örnek olarak Bauer ve Green'in (1996), Nahrgang, Morgeson ve Ilies'in (2009) ve Aude, Mitchell ve Cordes'in (2006) lider-takipçileri arasındaki ilişkinin oluşması ve gelişmesini inceledikleri çalışmalar gösterilebilir.

Araştırmada, astlar liderlerinin askeri liderliğini değerlendirmişlerdir. Her ne kadar yazar tarafından veri toplama safhasında katılımcilara bilgilerin gizli tutulacağ paylaşılmayacağı taahhüt edilmişse de astların, vereceği cevapları liderlerinin göreceğini düşünerek yüksek puan ve olumlu cevaplar verme eğiliminde oldukları değerlendirilmektedir. Araştırmada astların doğru cevap verdikleri varsayılmıştır.

Araştırmanın bir diğer kısıtı cinsiyettir. Esasen erkek egemen olan savunma sanayinde, araştırmanın örneklemini sadece erkek çalışanlar oluşturmaktadır. Dolaysıyla, cinsiyet değişkeni kontrol değişkeni olarak alınmamıştır.

İleriye yönelik araştırmalara ilk olarak, liderlerin kişiliğinin ve lider-ast kişilik uyumunun etkisinin incelenmesi önerilebilir. Bauer ve Green (1996) liderle astları arasında kaliteli bir ilişki geliştirmede kişilik benzerliğinin etkili olabileceğini öne sürmektedir. Bu tarz bir çalışma Zhang, Wang ve Shi (2012) tarafından yapılmıştır. Çalışmada yazarlar, lider ve izleyenin proaktif kişilik uyumuyla iş tatmini, duygusal bağlılık ve görev performansı arasında pozitif yönde ilişki bulunduğunu tespit etmişlerdir. Dolayısıyla, savunma alanında lider ve astı arasındaki kişilik uyumunun hem askeri liderlik hem de liderden tatmini nasıl etkilediği incelenebilir.

Araştırmada katılımcılar bağlı oldukları bir üst düzey konumdaki liderlerinin askeri liderliğini değerlendirmişlerdir. Dolayısıyla, araştırmaya konu olan liderler, farklı düzeylerde (orta, üst) liderlerdir. Walker (2008) Profesyonel Gelişim Çerçevesi Modeline göre liderin sahip olması gereken 16 
özelliğin odak noktası, kapsamı ve şiddetinin "alt, orta, ileri, kıdemli" düzeylere göre farklılaşacağını belirtmektedir. Dolayısıyla yeni geliștirilen askeri liderlik ölçeğinin de farklı düzeylere göre incelenerek, liderlerin sahip olması gereken özellikler ortaya konulabilir. Hunt (1991) geliştirdiği “Çok Düzeyli Liderlik Modeli”nde bu tarz bir çalışma yapmıştır. Çalışmasında, örgütsel etkinliği sağlamaya yönelik farklı liderlik düzeylerinde (sistem liderliği, örgütsel liderlik ve doğrudan liderlik) farklı çevresel faktörler, kritik görevler, bireysel yetenekler ve örgüt içi kültür/altkültürün bulunduğunu ve buna yönelik farklı özelliklere sahip olunması gerektiğini ortaya koymuştur.

Araştırmanın ileride savunma alanında faaliyet gösteren farklı kurumlarda tekrarlanması, bulguların genellenebilirliğini ve dış geçerliliğini artırarak, savunma sektöründeki gruplar arasında kıyaslama yapma olanağı sağlayabilir. Ayrıca ileriye yönelik olarak, askeri liderliğin astların duygusal bağl11ıkları, psikolojik dayanıklılıkları, örgütsel güvenleri, moralleri, motivasyonları, örgütsel adaletleri ya da lider-üye etkileşimlerine etkisine ve bu değişkenlerin aracılık ve düzenleyicilik etkilerine bakılarak; daha kapsamlı bir lider-ast ilişki incelemesi yapılabilir.

\subsection{Sonuç}

Liderin davranıșlarının astların liderden tatmini üzerindeki etkisini incelemek ve bu ilişkide astların kişilik özelliklerinin düzenleyici rolünü ortaya koymak maksadiyla savunma sanayindeki bir kurumun 390 çalışanı örneklemiyle yapılan araştırmada; askeri liderlikle astların liderden tatminleri arasında anlamlı ilişki bulunduğu; asta yönelik ilgi ve farkındalık boyutlarının astların liderden tatminini pozitif yönde etkilediği; ayrıca, astların kişilik özelliklerinden gelişime açıklık özelliğinin bu ilişkide düzenleyici rolünün bulunduğu ortaya konulmuştur.

$\mathrm{Bu}$ çalışmayla, liderin astlarına gösterdiği liderlik tarzının astların tutumları üzerindeki önemi vurgulanmıştır. $\mathrm{Bu}$ çalışma, liderlerin astlarına bireysel ilgi göstermesinin ve gelişmelerin farkında olarak uyum sağlama yetenekleri bulunmasının astların amirden tatminini etkileyeceğini; özellikle astların gelişime açıklıklarının yüksek olması durumunda, gelişime açıklığ düşük olan astlara nazaran daha fazla liderden tatmin olacaklarını göstermiştir. Bu çalışma ile hem teoriye hem de uygulamaya katk1 yapılarak; savunma alanında sağlıklı lider-ast ilişsisi geliştirilmesi, huzurlu bir çalışma ortamı yaratılması ve kurumsal amaçlara ulaşılması yönünde bir pencere açılmıştır.

\section{KAYNAKÇA}

Abdel-Halim, A. A. \& Rowland, K. M. (1976). Some personality determinants of the effects of participation: A further investigation. Personnel Psychology, 29(1), 41-55. doi: 10.1111/j.17446570.1976.tb00400.x

Aiken, L. S. \& West, S. G. (1991) Multiple regression: Testing and interpreting interactions, Newbury Park CA: SAGE.

Andrews, L. C. (2009). Leadership. İçinde R.L. Taylor, W.E. Rosenbach \& E.B. Rosenbach (Ed.), Military Leadership: In Pursuit of Excellence (s.s. 7-24) $(6$. Bask1), Boulder: Westview Press.

Aude, S. N., Mitchell, D. \& Cordes, G. B. (2006). Development and validation of leadership assessment instruments for United States army commanders, staff officers, and non-commissioned officers (NCOs). International Military Testing Association (IMTA) 2006 Annual Conference, Kingston, Ontario, Kanada, 2-5 Ekim

Aude, S. N., Karrasch, A., Leonard, A. \& Hatfield, J. (2006). U.S. army multi-rater (360) leader assessment and feedback pilot program. International Military Testing Association (IMTA) 2006 Annual Conference, Kingston, Ontario, Kanada, 2-5 Ekim.

Baron, R. M. \& Kenny, D. A. (1986). The moderatormediator variable distinction in social psychological research: Conceptual, strategic and statistical considerations. Journal of Personality and Social Psychology, 51(6), 1173-1182.

Barrick, M. R. \& Mount, M. K. (1991). The big five personality dimensions and job performance: A metaanalysis. Personnel Psychology, 44(1), 1-26. doi: 10.1111/j.1744-6570.1991.tb00688.x

Bass, B. M. (1990). Bass and Stogdill's handbook of leadership: Theory, research and managerial application (3.Bask1), New York: Free Press.

Bauer, T. N. \& Green, S. G. (1996). Development of leader-member exchange: A longitudinal test. Academy of Management Journal, 39(6), 1538-1567. doi: $10.2307 / 257068$

Benet-Martinez, V. \& John, O. P. (1998). Los cinco grandes across cultures and ethnic groups: Multitrait multimethod analysis of the big five in Spanish and English. Journal of Personality and Social Psychology, 75(3), 729-750. doi: 10.1037//00223514.75.3.729

Benoliel, P. \& Somech, A. (2014). The health and performance effects of participative leadership: Exploring the moderating role of the big five personality dimensions. European Journal of Work and Organizational Psychology, 23(2), 277-294. doi: 10.1080/1359432X.2012.717689

Brower, H. H., Schoorman, F. D. \& Tan, H. H. (2000). A model of relational leadership: The integration of trust and leader-member exchange. Leadership Quarterly, 11(2), 227-250. doi: 10.1016/S10489843(00)00040-0 
Cicerali, E. E. (2012). The effects of post-M\&A cultural change in organizations on individual and organizational performance: Moderated by personality and political skill (Yayımlanmamış Doktora Tezi), Yeditepe Üniversitesi Sosyal Bilimler Enstitüsü, İstanbul.

Chaplin, W. F. (1991). The next generation of moderator research in personality psychology. Journal of Personality, 59(2), 143-178.

Cohen, J., Cohen, P., West, S. G. \& Aiken, L. S. (2003). Applied multiple regression / correlation analysis for the behavioral sciences (3. Bask1), Mahwah, NJ: Erlbaum.

Costa, P. T. \& McCrae, R. R. (1980). Influence of extraversion and neuroticism on subjective wellbeing: Happy and unhappy people. Journal of Personality and Social Psychology, 38(4), 668-678. doi: 10.1037/0022-3514.38.4.668

Costa, P. T. \& McCrae, R. R. (1992). Revised neo personality inventory (NEO-PI-R) and neo five-factor (NEO-FFI): Inventory professional manual. Odessa, FL: Psychological Assessment Resources.

Dilek, H. (2005). Liderlik tarzlarının ve adalet algısının; Örgütsel bağlılık, iş tatmini ve örgütsel vatandaşlık davranışı üzerine etkilerine yönelik bir araştırma (Yayımlanmamış Doktora tezi). Gebze Yüksek Teknoloji Enstitüsü Sosyal Bilimler Enstitüsü, Gebze.

Dobbins, G. H. \& Zaccaro, S. J. (1986). The effects of groups cohesion and leader behavior on subordinate satisfaction. Group \& Organization Studies, 11(3), 203-219. doi: 10.1177/105960118601100305

Downey, H. K., Sheridan, J. E. \& Slocum, J. W. (1975). Analysis of relationships among leader behavior, subordinate job performance and satisfaction: A pathgoal approach. Academy of Management Journal, 18(2), 253-262. doi: 10.2307/255528

Dulebohn, J. H., Bommer, W. H., Liden, R. C., Brouer, R. L. \& Ferris, G. R. (2011). A meta-analysis of antecedents and consequences of leader-member exchange: Integrating the past with an eye toward the future. Journal of Management, 38(6), 1715-1739. doi: $10.1177 / 0149206311415280$

Eagly, A. H., Karau, S. J. \& Makhijani, M. G. (1995). Gender and the effectiveness of leaders: A metaanalysis. Psychological Bulletin, 117(1), 125-145.

Edwards, R. (2008). Discipline. İçinde B. Horn \& R. W. Walker (Ed.), Military Leadership Handbook (s.s. 228-243), Toronto: Dundurn Press.

Fernandez, S. (2008). Examining the effects of leadership behavior on employee perceptions of performance and job satisfaction. Public Performance \& Management Review, 32(2), 175-205. doi: 10.2753/PMR1530-9576320201

Fiedler, F. E. (1954). Assumed similarity measures as predictors of team effectiveness. Journal of Abnormal and Social Psychology, 49(3), 381-388. doi: 10.1037/h0061669

Fiedler, F. E., Bass, A. M. \& Fiedler, J. M. (1961). The leader's perception of coworkers, group climate, and group creativity: A cross validation. Urbana, Illinois: Group Effectiveness Research Laboratory, University of Illinois.

Field Manual (FM) 22-100. (1999). Army leadership: be, know, do. Washington D.C.: Department of the Army.

Gerstner, C. R. \& Day, D. V. (1997). Meta-analysis review of leader-member exchange theory: Correlation and construct issues. Journal of Applied Psychology, 82, 827-844.

Gürbüz, S. \& Şahin, F. (2014). Sosyal bilimlerde araştırma yöntemleri. Ankara: Seçkin Yayıncılık.

Hobfoll, S. E. (1989). Conservation of resources: A new attempt at conceptualizing stress. American Psychologist, 44(3), 513-524. doi: 10.1037/0003066X.44.3.513

Hobfoll, S. E. (2001). The influence of culture, community, and the nested-self in the stress rocess: Advancing conservation of resources theory. Applied Psychology: An International Review, 50(3), 337-369. doi: 10.1111/1464-0597.00062

Hobfoll, S. E. \& Lily, R. S. (1993). Resource conservation as a strategy for community psychology. Journal of Community Psychology, 21(2), 565-589. doi: $\quad 10.1002 / 1520-6629(199304) 21: 2<128:: A I D-$ JCOP2290210206>3.0.CO;2-5

Hobfoll, S. E. \& Shirom, A. (2001). Conservation of resources theory: Applications to stress and management in the workplace. İçinde R.T. Golembiewski (Ed.), Handbook of Organizational Behavior (s.s. 57-80), New York, NY: Dekker.

Horn, B. (2008). Combat Motivation. İçinde B. Horn \& R. W. Walker (Ed.), Military Leadership Handbook (s.s. 73-90), Toronto: Dundurn Press.

Horn, B. \& Walker, R. W. (2008). Military Leadership Handbook. Toronto: Dundurn Press.

Judge, T. A., Piccolo, R. F. \& Ilies, R. (2004). The forgotten ones? The validity of consideration and initiating structure in leadership research. Journal of Applied Psychology, 89(1), 36-51. doi: 10.1037/0021-9010.89.1.36

Hunt, J. G. (1991). Leadership: A New Synthesis. Newbury Park, CA: Sage.

Künter, N. (2014). Askeri liderlik: Kavramlaştırma ve askeri liderin etkinliğinin ölçümüne ilişkin bir ölçek geliştirme çabası (Yayımlanmamış Yüksek Lisans Tezi), Kara Harp Okulu Savunma Bilimleri Enstitüsü, Ankara.

Meuwese, W. A. T. (1964). The effect of the leader's ability and interpersonal attitudes on group creativity under varying conditions of stress (Yayımlanmamış Doktora Tezi), Amsterdam: University of Amsterdam.

Morris, T. (1995). Employee satisfaction: Maximizing the return on human capital. CMA - The Management Accounting Magazine, 69(10), 15-18.

Mumford, M. D., Zaccaro, S. J., Harding, F. D., Jacobs, T. O. ve Fleishman, E. A. (2000). Leadership skills 
for a changing world: Solving complex social problems. Leadership Quarterly, 11(1), 11-35.

Nahrgang, J. D., Morgeson, F. P. \& Ilies, R. (2009). The development of leader-member exchanges: Exploring how personality and performance influence leader and member relationships over time. Organizational Behavior and Human Decision Processes, 108(2), 256-266. doi: 10.1016/j.obhdp.2008.09.002

Podsakoff, P. M., MacKenzie S. B., Lee, J. Y. \& Podsakoff, N. P. (2003). Common method biases in behavioral research: A critical review of the literature and recommended remedies. Journal of Applied Psychology, 88(5), 879-903. doi: 10.1037/00219010.88.5.879

Randall, E. W. (2006). Military leadership: The effect of leader behavior on soldier retention in the army national guard (Yayımlanmamış Doktora Tezi), Capella Üniversitesi.

Schmitt, D. P., Allick, J., McCrae, R. R. \& BenetMartinez, V. (2007). The geographic distribution of big five personality traits: Patterns and profiles of human self-description across 56 nations. Journal of Cross-Cultural Psychology, 38(2), 173-212. doi: $10.1177 / 0022022106297299$

Spector, E. P. (1985). Measurement of human service staff satisfaction: Development of the job satisfaction survey. American Journal of Community Psychology, 13(6), 693-713. doi: 10.1007/BF00929796

Stogdill, R. M. (1974). The handbook of leadership: A survey of theory and research. New York: Free Press.

Sun, Ö. (2002). İş doyumu üzerine bir araştırma: Türkiye Cumhuriyet Merkez Bankası (Yayımlanmamış Uzmanlık Yeterlilik Tezi), Türkiye Cumhuriyet Merkez Bankası Banknot Matbaası Genel Müdürlüğü, Ankara.

Sümer, N. \& Sümer. H. C. (2005). Beş faktör kişilik özellikleri ölçeği (Yayınlanmamış çalışma). Ankara.

Şahin, F. (2011). The interaciton of self-leadership and psychological climate on job performance. African Journal of Business Management, 5(5), 1787-1794. doi: 10.5897/AJBM10.763.

Tabak, A. (1997). Askeri liderlik ve uygulama (Yayımlanmamış Yüksek Lisans Tezi). Gazi Üniversitesi Sosyal Bilimler Enstitüsü, Ankara.

Taylor, R. L., Rosenbach, W. E. \& Rosenbach, E. B. (2009). Military leadership: In pursuit of excellence (6. Baskı), Boulder: Westview Press.

Tosi, H. L. (1973). The effect of the interaction of leader behavior and subordinate authoritarianism. Personnel Psychology, 26(3), 339-350. doi: 10.1111/j.17446570.1973.tb01141.x

Uhl-Bien, M. (2006). Relational leadership theory: Exploring the social processes of leadership and organizing. Leadership Quarterly, 17(6), 654-676.

Vecchio, R. P. (1981). Situational and behavioral moderators of subordinate satisfaction with supervision. Human Relations, 34(11), 947 - 963. doi: $10.1177 / 001872678103401103$
Walker, R. W. (2008). The professional development framework. B. Horn ve R. W. Walker (Ed.), Military Leadership Handbook içinde (s.s. 436-450), Toronto: Dundurn Press.

Watson, D. \& Clark, L. A. (1997). Extraversion and its positive emotional core. İçinde R. Hogan, J. A. Jobnson ve S. R. Briggs (Ed.), Handbook of Personality Psychology (s.s. 767-793), San Diego: Academic Press.

Wells, J. E. \& Peachey, J. W. (2011). Turnover intentions: Do leadership behaviors and satisfaction with the leader matter? Team Performance Management, 17(1/2), 23-40. doi: $10.1108 / 13527591111114693$

Wong, L., Bliese, P. \& McGurk, D. (2003). Military leadership: A context specific review. The Leadership Quarterly, $14, \quad 657-692 . \quad$ doi: 10.1016/j.leaqua.2003.08.001

Wood, M. T. \& Sobel, R. S. (1970). Effects of similarity of leadership style at two levels of management on the job satisfaction of the first level manager. Personnel Psychology, 23(4), 577-590. doi: 10.1111/j.1744-6570.1970.tb01374.x

Yukl, G. A. (2010). Leadership in organizations (7. Bask1), Upper Saddle River, NJ: Prentice Hall.

Zhang, Z., Wang, M. \& Shi, J. (2012). Leader-follower congruence in proactive personality and work outcomes: The mediating role of leader-member exchange. Academy of Management Journal, 55(1), 111-130. doi: 10.5465/amj.2009.0865 